\title{
Erratum to: Lumbosacral intrathecal nerve roots: an anatomical study
}

\author{
Mehmet Arslan • Ayhan Cömert • Halil İbrahim Açar • Mevci Özdemir • \\ Alaittin Elhan • İbrahim Tekdemir • Richard Shane Tubbs • Ayhan Attar • \\ Hasan Çağlar Uğur
}

Published online: 5 January 2013

(C) Springer-Verlag Wien 2013

\section{Erratum to: Acta Neurochir (2011) 153:1435-1442 \\ DOI 10.1007/s00701-011-0952-2}

The original version of this article unfortunately contained mistake. The name of "Richard Shane Tubbs" was incorrectly written and is now corrected in the author group of this article.

The online version of the original article can be found at http://dx.doi.org/ 10.1007/s00701-011-0952-2.

M. Arslan

Department of Neurosurgery, Yuzuncu Y1l University,

Faculty of Medicine,

Van, Turkey

A. Cömert $(\bowtie) \cdot$ H. İ. Açar • A. Elhan · İ. Tekdemir

Department of Anatomy, Ankara University, Faculty of Medicine,

Ankara, Turkey

e-mail: comertayhan@yahoo.com

M. Özdemir

Neurosurgery Clinic, Ergani State Hospital,

Diyarbakir, Turkey

R. S. Tubbs

Pediatric Neurosurgery, Children's Hospital,

Birmingham, AL, USA

A. Attar • H. Ç. Uğur

Department of Neurosurgery, Ankara Üniversitesi Tip Fakültesi,

İbni Sina Hastanesi Beyin Cerrahisi,

06100 Sihhiye, Ankara, Turkey

H. Ç. Uğur

e-mail: ugurhc@yahoo.com 